日臨外会誌 65 (6), 1491-1495, 2004

症例

MRI の血流パターンが乳癌との鑑別に有用と考えられた 乳腺線維腫症の 1 例

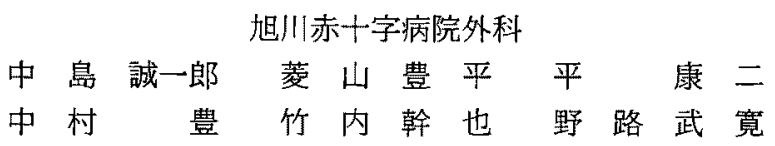

乳腺線維腫症は稀な疾患であり本邦の症例報告数も僅かである．最近われわれは乳腺 線維腫症の 1 例を経験したので報告する. 症例は56歳，女性． 2 年前から右乳房 BD 領 域の腫瘤を自賞し增大したため来院した。腫瘤は $10 \times 3 \mathrm{~cm}$ 大で弾性硬, 胸壁固定と皮简 楩山を認めた，USでは乳腺の最深部に low echoic massがあり辺縁は不整で，CTでは 胸壁に浸潤を疑わせる low density area を認めた。しかし造影 MRIによる血流パター ンは良性パターンに一致していた，ドリル生検を行うも腫崵成分はなく確定診断には至 らなかった。乳癌を否定できず, incisional biopsy 在行ったところ迅速病理診断にて徳 性所見なく，腫瘤部の切除のみを行った。病理診断は乳腺線維腫症であった，乳腺線維 腫症は画像上乳癌との鑑別が困難であるが, MRI の血流パターンは乳癌と乳腺線維腫症 の鑑別に有用であると考えられた。

索引用語：乳腺嗹㾮, 乳腺線維腫症, MRI

\section{緒言}

乳腺線維腫症は線維芽細胞が浸潤性增殖する良性の 腫演性疾患である。局所再発率が高いが，遠隔転移は ない. 非常に稀であり本邦では自験例を含めて15例で あった．臨床上癌との鑑別がしばしば問題となる．今 回われわれはMRIによる血流パターンが癌との鑑別 に有用と考えられた乳腺線維腫症の1例を経験したの で，若干の文献的考察を加え報告する.

$$
\text { 症例 }
$$

症例：56歳，女性.

主訴：右乳房のしこり.

現病歴：約 2 年前より右乳房のしこりを自覚してい た. 2002 年10月当科外来を受診した.

家族歴，既往歴：特記すべきことなし.

現症：右乳房 $\mathrm{BD}$ 領域に約 $10 \times 3 \mathrm{~cm}$ 大, 弾性硬, 境 界不明瞭な腫瘤を触知した。胸壁固定および皮豦陥凹 を認めた。

検査所見：血液検査に特記事項なく, CEA, CA15-

2003年12月 3 日受付 2004 年 3 月16日採用

〈所属施設住所〉

干070-8530 旭川市曙一条 1 丁目 1-1
3 は正常範囲内であった。

乳腺撮影：Inframammary foldに一致して横長で, 不整形,一部スピキュラを伴う high density の腫瘤陰 影を認めた。石灰化所見は認めなかった（图 1 )。

乳腺超音波検査: 乳腺の最深部に横長の棈円形, 境 界不整で内部エコーがほほ均一な low echoic massが 認められた。前方境界線の断裂はなく，後方境界線の 断裂が虫められ, 後方エコーの減弱, 增強は認めなか った（図2)。

乳房 CT 検査 : 腫瘤に一致して筋肉組織とほほ同じ 漲度の領域が認められ，胸壁浸潤が疑われた（図 3 )。

乳房 MRI 検查：肋間筋に浸潤している所見が認め られた（図 4)。一方乳房 MRIの血流パターンを示す T1 強調像による dynamic 曲線 (以下 T1-DyMRM) は明らかな濑增型を示し，悪性腫嚗の示す急峻型では なかった。またecho-planar(EPI) 法を用いたdynamic MRI (dynamic susceptibility contrast MRI : 以下 DSC-MRI）の dynamic 曲線も bolus 静注後30秒以内 の信号強度の著明な低下はみられず，乳癌ではなく良 性疾患であることが示唆された（図5)。

穿刺吸引細胞診: 脂肪組織七結合織のみで悪性所見 はなかった。 


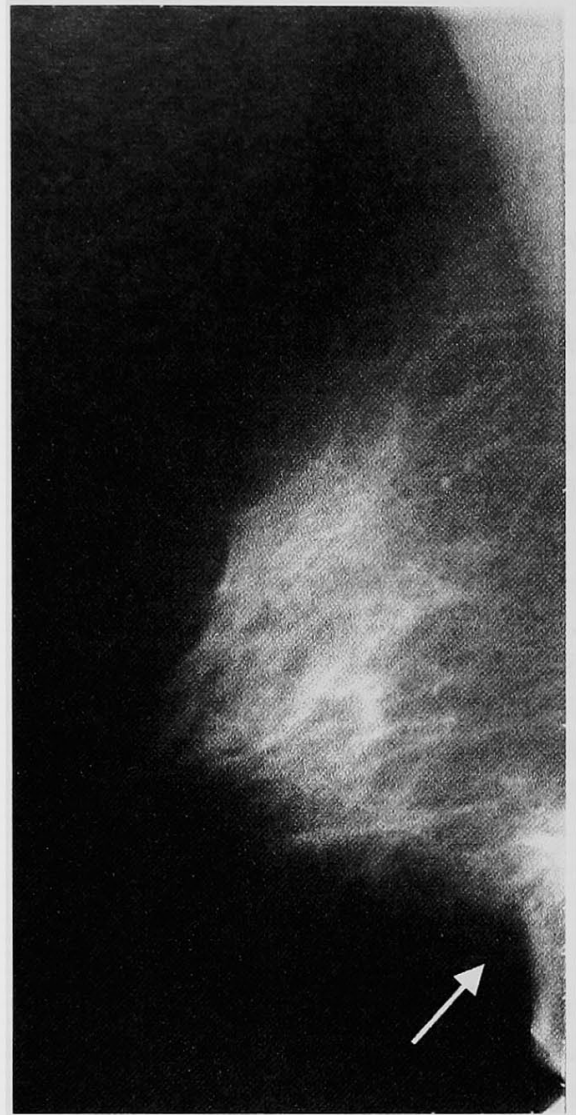

図 1 乳腺撮影：矢印で示した部分に腫瘤陰影 の一部を認めた．石灰化所見は認めなかった。

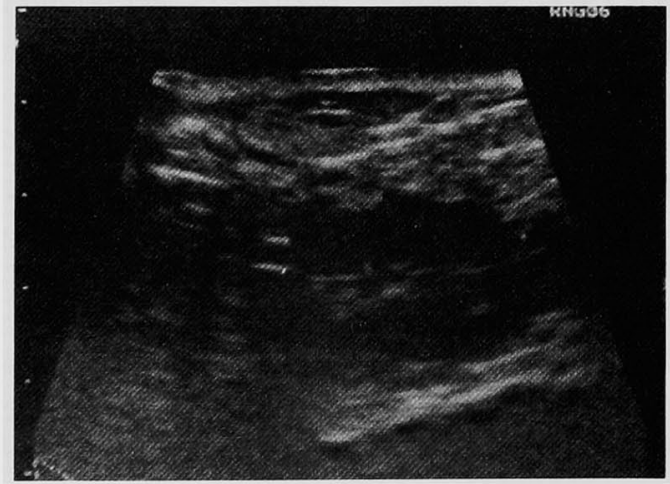

図 2 乳腺超音波検査：乳腺の最樑部に内部エコーがほ ほ均一にlow な腫瘤が認められた。

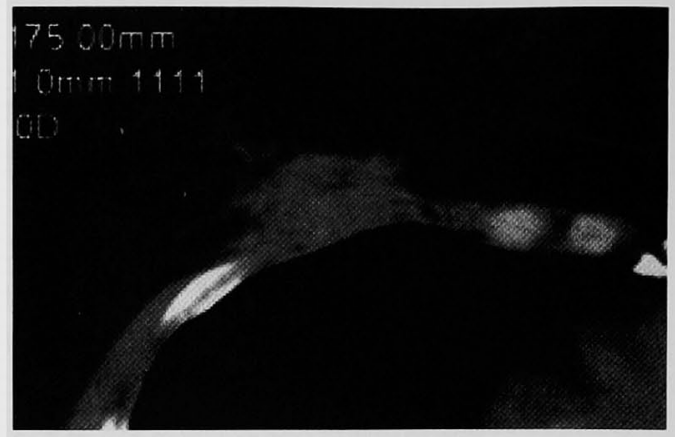

図 3 乳房 CT 検査：腫瘤に一致して筋肉組織とほほ同 じ濃度の領域が認められ胸壁浸潤が疑われた。

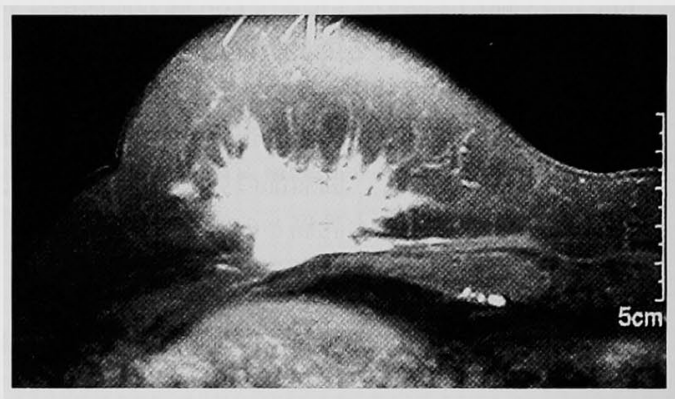

図 4 乳房 MRI 検査 : 肋間筋に浸潤している所見が認 められた。

以上の所見から，浸潤増殖性の良性疾患が考えられ たが完全には乳癌を否定できず，2002年11月11日手術 を施行した。

手術所見：Inframammary foldに一致した弧状切 開で, incisional biopsy を施行したところ，術中迅速 病理診断は hyalinosis (硝子化組織)であったため, 腫 瘤切除術のみを施行した。

病理組織所見：膠原組織を伴った紡鍾形細胞が筋組 織に浸潤している像が認められた．紡鍾形の線維芽細 胞が束状あるいは渦巻き状に増殖しており，核の異型 に乏しく分裂像はみられなかった(図6). 以上より乳 腺線維腫症と診断された。

術後経過は良好で術後約 6 力月を経た現在再発は認 められない.

考 察

線維腫症は分化した線維芽細胞の浸潤性増殖を示す 腫济であり，別名デスモイド腫瘍と呼ばれる。切除後 に局所再発する場合があるが遠隔転移はない1). 腹壁, 腹壁外，腹腔内の 3 つに大別され，腹壁に発生するの 


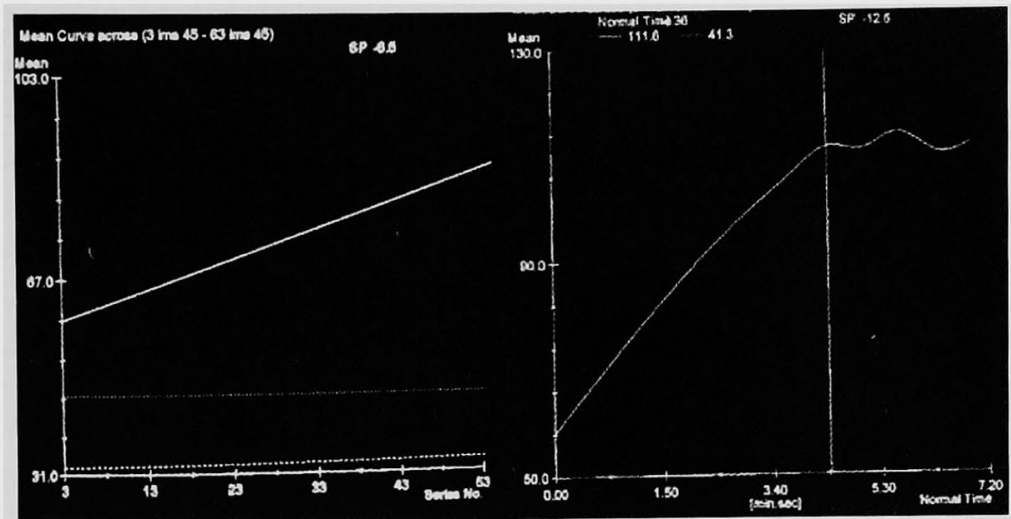

図 5 MRI 血流曲線：T1-DyMRM の dynamic 曲線は明らかな漸増型を示し（図 右), DSC-MRI の dynamic 曲線も信号強度の著明な低下はみられなかった。
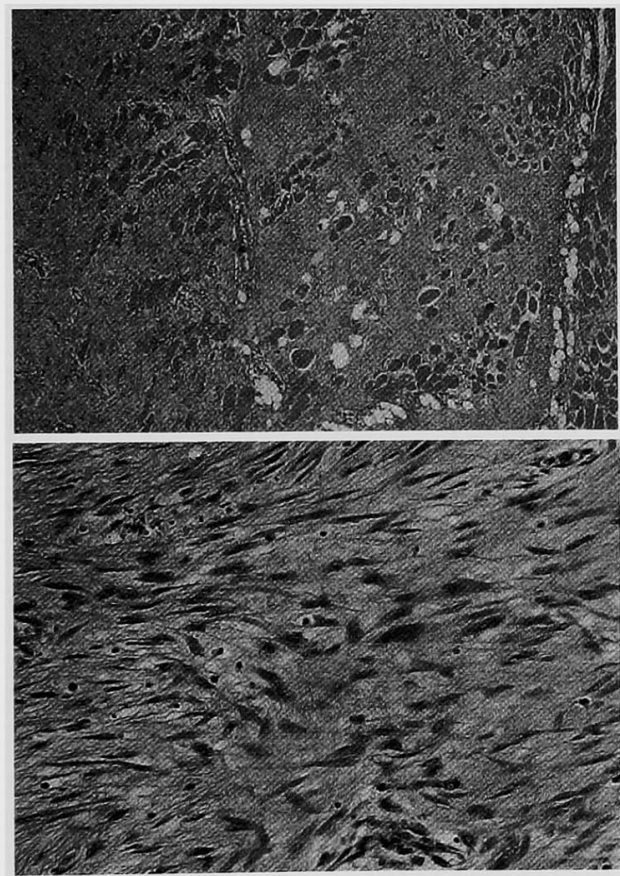

図 6 病理組織所見：a）膠原組織を伴った紡錘形細 胞が肋間筋組織に浸潤している像が認められた。 b) 紡錘形の線維芽細胞が束状あるいは渦巻き状に 増殖しており,核の異型に乏しく分裂像はみられな かった（a：HE染色, $\times 10, b$ ：HE染色, $\times 50)$.

$\frac{a}{b}$
が主であり乳腺原発例は非常に稀で，本邦では自験例 を含めると15例であった（表 1$)^{11 ー 13) . ~}$

発症年齢は本邦報告例では20歳〜90歳にみられた が，20代が多く，平均年龄は37.3歳であった. Rosen ら ${ }^{14)}$ によれば14歳〜80歳で中央値が25歳であり若年者 に多く，本邦報告例と類似していた。

発症要因としては外傷, 手術による機械的影響, 妊 娠, 性周期に伴うホルモンの影響, Gardner 症候群の ような遺伝的背景などが挙げられているが末だ不明な 点が多い，本邦報告例では乳腺手術の既往は 2 例に認 めたが，他の症例では発症に結びつく要因は認められ なかった。

乳腺線維腫症は臨床診断において乳癌との鑑別が困 難で, 触診上腫瘤が硬く境界不明瞭であり, 乳頭・皮 咸陥出が認められることも多い. 乳腺撮影は充実性腫 瘤像を呈することが多く特徴的な所見はない. 乳房超 音波検查でも内部不均一な低エコー像で後方エコー増 強，あるいは減衰など様々な所見が報告されている。 穿刺吸引細胞診では異型性のない紡錘形の細胞, 正常 乳管上皮細胞，リンパ球などがみられたためClass I と診断されるか, N/C 比の高い核形不整の紡錘形細胞 の集団が孤立散在性にみられたため葉状腫瘍，あるい は非上皮性腫眗と診断される場合が多い.

一方本症例において T1-DyMRM およびDSCMRI の dynamic 曲線は乳癌と異なる良性疾患の血流

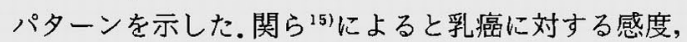
特異度は T1-DyMRM が96\%，88\%, DSC-MRI は93 $\% ， 100 \%$ あ゙あ，乳腺腫瘍の良・悪性の判別には非常 に有効である．本症例のように，良・悪性の鑑別が困 
表 1 乳腺線維腫症本邦報告例

\begin{tabular}{|c|c|c|c|c|c|c|c|c|c|c|}
\hline 番号 & 郝告者 & 城告年 & 年都 & 情别 & 大きき(cm) & 部位 & 臯往歷 & 賴胞韵 & 手㘺 & 再発 \\
\hline 1 & Hashimoto & 1986 & 23 & 婎 & $4.0 \times 1.0$ & 左决 & 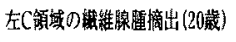 & 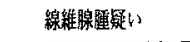 & extensive excision & な \\
\hline$?$ & 宪峘 & 1989 & 23 & 女姓 & $5.5 \times 5.0$ & 㠻)全本 & 特記事碩放 $L$ & 葉新遠雷 & subcutaneous mastectomy & な \\
\hline 3 & 藤本 & 1993 & 25 & 女性 & $2.0 \times 2.0$ & 古)AC & 心室中隔欠揭(6歳) & 阷行せず & tumorectomy & 不明 \\
\hline 4 & Koibuchi & 1994 & 21 & 文性 & $4.2 \times 3 . \hat{i}$ & 右)CE & 特記事頂なL & atypical fibroacenoma & extensive excision & 4月月後 \\
\hline$j$ & 田村 & 1994 & $2-i$ & 如住 & 5.24 .9 & 新AC & 特部事項なし & Classill & tumorectomy & 7九月後 \\
\hline 6 & 田村 & 1994 & $2 ?$ & 女性 & $3.3 \times 3.0$ & 古)ED & 特記事傎公L & Class I & tumorectony & 3力後 \\
\hline$i$ & 木 & 1995 & 20 & 女性 & $\begin{array}{l}2.0 \times 2.1(A) \\
2.0 \times 2.0(D)\end{array}$ & 右) $A, D$ & 特記事須なし & 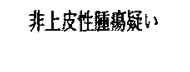 & tumorectony & 新 \\
\hline 8 & Nagaoka & 1997 & 51 & 如 & $4.1 \times 3.0$ & 右)C & 記载尔し & 澵行せず & quadrantectomy & 㧠 \\
\hline 9 & 大埼 & 1998 & 56 & 女性 & $6.8 \times 4.0$ & 左)C & 等記事䪱如L & Class 1 & quadrantectomy & 机 \\
\hline 10 & 清野 & 1999 & 90 & 女姓 & $3.0 \times 3.0$ & 左)CD & 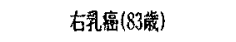 & 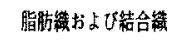 & partial mastectomy & 13 周後执よひ20力月後 \\
\hline 11 & 沼本" & 2001 & 36 & 交性 & $2.8 \times 2.5$ & tAAC & 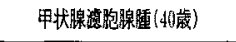 & 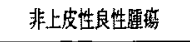 & tumorectomy & 不明 \\
\hline 12 & Yamaguchi & 2002 & 36 & 女性 & $1.2 \therefore 1 . \bar{i}$ & 左) B & 記載なし & 换体不十分 & tumorectomy & なL \\
\hline 13 & Nakano & 2002 & 46 & 女姓 & $3.7 \times 3.7$ & 左) & 左E钼域门生強(43藏) & 区応惟咨化 & mastectomy & 就 \\
\hline 14 & 吉本 & 2002 & 20 & 女性 & $\begin{array}{l}5.5 \times 6.0\left(\frac{1}{1}\right) \\
3.5 \times 1.0(16)\end{array}$ & $\begin{array}{c}\text { 方)全体, } \\
\text { 右保 }\end{array}$ & 特記事項なし & 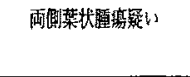 & tumorectomy & 5 力月後(古) \\
\hline 15 & 自騤䔳 & 2003 & 56 & 女姓 & $10.0 \times 3.0$ & 右 $\mathrm{BD}$ & 特記事頃なし & 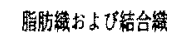 & tumorectomy & 新 \\
\hline
\end{tabular}

追記）*：左乳腺に葉状嗹場を認めた。

難な乳腺腄惶に対し MRIの血流パターンを積極的に 調べることは，より正確な診断の一助になると考えら れた。

治療は wide resectionが第一選択であり皮膚，筋 膜，筋肉など浸潤部位があれば切除範囲をさらに広げ 腫癔をすべて謫出すべきであると報告されている 同所再発率は本邦では33\%（15例中 5 例），欧米でも 21〜27\%であっだ'年，また再発までの期間は本邦では 約 1 年以内に再発することがほとんどで，1年を過ぎ てからの再発は 5 例中 1 例のみであった。欧米では 2 $\sim 3$ 年以内の再発が多いとされている ${ }^{161}$. 再発に対し ても外科的切除が第一選択であり，術後の radiochemotherapy は無効であるといわれている17!. 本症 例でも局所再発に対し慎重に follow upしていきたい と考えている.

\section{結語}

今回われわれは56歳女性の乳腺線維腫症の1例を経 験した。浸潤増殖性の画像を呈したが，MRIの血流パ ターンが乳癌との鑑別に有用であった，局所再発が高 頻度に認められるため術後の慎重な follow up が重要 であると考えられた。

\section{女 献}

1) 田村 光, 池田 正, 榎本耕治他：乳腺線維腫症 Mammary Fibromatosis 2 例。乳癌の臨 $9: 587-592, \quad 1994$

2) Hashimoto $K$, Ito $H$, Okamura $R$, et al : Aggressive fibromatosis infiltrating breast. Report of case and review of literature. Kobe J Med Sci $32: 59-70,1986$

3）光山昌珠，勝本富士夫，坂田正毅他：乳腺線維腫 症の 1 例。外科 $51: 297-299,1989$

4) 藤本康二, 西村理, 松末智: 乳房原発 Fibromatosis 01 例。超音波医 $21: 165-168$, 1994

5) Koibuchi $Y$, lino $Y$, Oyama $T$, et al : Firomatosis of the Breast: A case report. Jpn J Clin Oncol 25:16-19, 1995

6）木村英明，森脇義弘，山腰英紀他：乳腺線維腫症 (Fibromatosis of the breast) 01 例. 横浜医 $46: 89-93,1995$

7) Nagaoka H, Higashi $Y$, Suematsu $K$, et al : Fibromatosis of the Breast:A case report. Breast Cancer $4: 121-125,1997$ 
8）大崎博之, 高田多津夫, 中村宗男：乳腺に発生し た線維腫症 fibromatosis $の 1$ 例。日蹋細胞会誌 $37: 318-322,1998$

9) 清野徳彦, 奥田康一, 西脇 真他：乳腺線維腫症 (Fibromatosis of the Breast) $の 1$ 例. 乳癌の 臨 $14: 280-283,1999$

10）沼本 敏：境界明瞕字乳腺線維腫症の 1 例。診断 病理 $18: 52-54,2001$

11) Yamaguchi $H$, Sakakibara $T$, Hino $M$, et al : A case of fibromatosis of the breast. Breast Cancer 9:175-178, 2002

12) Nakano $S$, Ohtsuka $M$, Hasegawa $T$, et al: Fibromatosis of the breast: A case report. Breast Cancer 9:179-183, 2002

13）吉本信保，遠山竜也，山下啓子他：両側乳腺線維 尰症 (fibromatosis of the breast) の1例. 日臨
外会誌 $64: 575-579,2003$

14) Rosen PP, Ernsberger D: Mammary fibromatosis: A benign spindle-cell tumor with significant risk for local recurrence. Cancer $63: 1363-1369,1989$

15) 関 恒明, 吉野綾子, 蜂屋順一：特集 乳腺の画 像診断 update, 乳腺 MRI 診断の現況, 画像診断 18:918-929, 1998

16) Thomas T, Lorino C, Ferrara JJ : Fibromatosis of the breast. A case report and literature review. J Surg Oncol 35:70-74, 1987

17) Rosen PP, Oberman HA : Tumors of the mammary gland. Ed. Rosai. J and Sobin LH, In: Atlas of Tumor Pathology, 3, Armed Forces Institute of Pathology, Washington DC, 1992, p306-310

\title{
A CASE OF BREAST FIBROMATOSIS IN WHICH BLOOD FLOW PATTERN IN MRI APPEARED TO BE HELPFUL FOR DIFFERENTIATION FROM BREAST CANCER
}

\author{
Seiichiro NAKAJIMA, Hohei HISHIYAMA, Koji TAIRA, \\ Yutaka NAKAMURA, Mikiya TAKEUCHI and Takehiro NOJI \\ Department of Surgery. Asahikawa Red Cross Hospital
}

Breast fibromatosis is a rare entity and has been reported in few cases in Japan. This paper describes such a rare case of breast fibromatosis.

A 56-year-old woman was seen at the hospital because of an enlarging tumor in the $\mathrm{BD}$ area of the right breast which had first been felt since 2 years earlier. The tumor was $10 \times 3 \mathrm{~cm}$ in diameter and elastic hard. Fixation of the tumor to the chest wall and dermal depression were noted. Ultrasonic scans showed a low echoic mass with heterogeneous margin in the deepest part of the breast. CT scans visualized a low density area suggestive of invasion into the chest wall. However, blood flow pattern in magnetic resonance imaging (MRI) scans was identical with benign pattern. Drill biopsy did not demonstrate tumor components and no definite diagnosis was made. Because a possibility of breast cancer could not be ruled out, an incisional biopsy was carried out when no malignant evidence was obtained by intraoperative frozen section diagnosis. And only the tumor was removed. Histopathological diagnosis was breast fibromatosis.

We often have difficulties in differentiating breast fibromatosis from breast cancer on imaging methods. It is thought that blood flow pattern in MRI might be helpful for differentiation between them. 